\title{
The Aberrant Expression of Cytokeratin in Plasma Cell Neoplasm
}

\author{
Hiroaki SUZUKI ${ }^{1}$, Katsushige YAMASHIRO ${ }^{1}$, Mitsutoshi KUROSAWA ${ }^{2}$ \\ ${ }^{1}$ National Hospital Organization Hokkaido Cancer Center, Division of Diagnostic Pathology, \\ ${ }^{2}$ National Hospital Organization Hokkaido Cancer Center, Division of Hematology, Sapporo, JAPAN
}

\begin{abstract}
It is known that cytokeratin $(\mathrm{CK})$ is aberrantly expressed in a subset of plasma cell myelomas. We investigated the expression of CK (CAM5.2, AE1/AE3) in fifty consecutive cases of plasma cell neoplasms (plasma cell myeloma, $n=43$; solitary plasmacytoma of bone, $\mathrm{n}=7$ ). Seven (plasma cell myeloma, $\mathrm{n}=5$; solitary plasmacytoma of bone, $\mathrm{n}=2$ ) of the 50 cases were positive for CK (CAM5.2: $7 / 50$, AE1/AE3: 0/50). The seven cases also expressed CK7 (2/7), CK8 (3/7) and CK18 (7/7) with varying intensity. One case was positive (>10\%) for both CK8 and CK18 and two cases weakly expressed both CK8 and CK18 ( $\leq 10 \%)$. CK8 and CK18 are expression partners and are known to form heteropolymeric filament in cells, suggesting that heteropolymeric filament is formed in a subset of plasma cells in myeloma. On the other hand, the seven cases expressed both type I cytokeratin (CK18) and type II cytokeratin (CAM5.2). CAM5.2 primarily reacts with CK8 and to a lesser extent with CK7. Although the CK8 antibody that was used only reacted with 3 of the 7 cases, it is likely that all 7 cases expressed both CK8 and CK18. The follow-up survival data did not show a significant difference between the CAM5.2-positive group and the CAM5.2-negative group.
\end{abstract}

Keywords: Cytokeratin, Keratin, Myeloma, Immunohistochemistry, Plasma cell, CK8, CK18, CAM5.2

ÖZET

Plazma Hücreli NeoplazmPnda Cytokeratin'in Anormal Ekspresyonu

Sitokeratin (CK), plazma hücreli miyelomların bir alt kümesinde anormal eksprese olduğu bilinmektedir. Elli ardışık plazma hücreli neoplazm (plazma hücreli miyelom, $n=43$, kemiğin soliter plazmasitomu, $n=7$ ) olgusunda CK (CAM5.2, AE1 / AE3) ekspresyonunu araştırdık. 50 olgunun yedisi (plazma hücreli miyelom, $n=5$, soliter kemik plazmositomu, $n=2$ ) CK pozitifti (CAM5.2: 7/50, AE1/AE3: 0/50). Yedi vaka aynı zamanda değişen şiddette CK7 (2/7), CK8 (3/7) ve CK18 (7/7) eksprese etmiştir. Bir olgu, hem CK8 hem de CK18 için pozitifti (>\% 10) ve iki olgu hem CK8 hem de CK18'i zaylf biçimde eksprese idi ( $\leq \%$ 10). CK8 ve CK18, ekspresyon partnerleridirler ve hücrelerde, heteropolimerik filamentin miyelomadaki plazma hücrelerinin bir alt kümesinde oluştuğunu düşündüren, heteropolymeric filament oluşturduğu bilinmektedir. Öte yandan, yedi olguda hem tip I sitokeratin (CK18) hem de tip II sitokeratin (CAM5.2) eksprese edildi. CAM5.2 öncelikle CK8 ile reaksiyona girer ve daha az ölçüde CK7 ile reaksiyona girer. Kullanılan CK8 antikoru ancak 7 olgunun 3'ü ile reaksiyona girmiş olsa da, muhtemelen 7 olgunun ikisinin de CK8 ve CK18'i eksprese ettikleri muhtemeldir. İlem sağkalımı verileri, CAM5.2-pozitif grup ile CAM5.2-negatif grup arasında anlamlı bir fark göstermedi.

Anahtar Kelimeler: Sitokeratin, Keratin, Miyelom, Immünohistokimya, Plazma hücresi, CK8, CK18, CAM5.2 


\section{INTRODUCTION}

Plasma cell myeloma is a multifocal plasma cell neoplasm and solitary plasmacytoma of bone is a localized plasma cell neoplasm. ${ }^{1}$ Both plasma cell myeloma and solitary plasmacytoma of bone show the same immunophenotype and genetic characteristics. $^{1}$

Cytokeratins (CKs) are intermediate filament proteins that can be found in epithelial cells. ${ }^{2,3} \mathrm{CKs}$ consist of at least 20 gene products and a large number of hair follicle-specific epithelial CKs have recently been discovered. ${ }^{2,3} \mathrm{CKs}$ are classified into two groups: type I (acidic, CK9-CK20) and type II (basic to neutral, CK1-CK8). Heteropolymeric filaments are formed by the pairing of type I CK and type II CK in a 1:1 ratio. ${ }^{2,3} \mathrm{CKs}$ are important for the mechanical stability and integrity of epithelial cells and tissue. ${ }^{2,3}$ CKs are thought to work as an intracellular scaffold. Some CKs (CK8 and CK18) are involved in the intracellular signaling pathways and may affect carcinogenesis., ${ }^{2,3}$

Sewell et al. first reported a case of plasma cell myeloma showing monoclonal antibody CAM5.2 immunoreactivity. ${ }^{4}$ CAM 5.2 is known to react with type II CK (primarily CK8 and to a lesser extent CK7). ${ }^{5}$ Wotherspoon et al. showed CK immunoreactivity in 5 of 14 casee of plasmacytoma (36\%, solitary plasmacytoma of bone and plasma cell myeloma). ${ }^{6}$ Three cases showed immunoreactivity to CAM5.2 (21\%) and the other two cases showed immunoreactivity to K13 (type I, 14\%). Petruch et al reported that $8 \%$ of 51 multiple myeloma cases showed immunoreactivity to KL-1. ${ }^{7} \mathrm{KL}-1$ is known to react with type I CK and type II CK (CK1, 2, 5, 6, 7, 8, 11, 14, 16, 17 and 18). ${ }^{2}$

To our knowledge, it is not known whether both type I CK and type II CK are simultaneously expressed in plasma cell neoplasms.

We studied the expression of CKs in 50 plasma cell neoplasms (plasma cell myeloma, $n=43$; solitary plasmacytoma of bone, $n=7$ ) and compared the survival of the CAM5.2-positive and CAM5.2negative groups.

\section{PATIENTS and METHODS}

\section{Patients}

We investigated 50 consecutive cases of plasma cell neoplasms (plasma cell myeloma, $n=43$; solitary plasmacytoma of bone, $n=7$ ) that were pathologically diagnosed in the Hokkaido Cancer Center between 1998 and 2013. The study population included 23 male patients and 27 female patients. The median age at the time of the diagnosis was 64 years (range, 32 to 88 years). According to Durie Salmon stage system 8,12 patients presented with stage I, 4 patients presented with stage II, and 34 patients presented with stage III.

This study was approved by the Ethical Committee of the Hokkaido Cancer Center.

\section{Immunohistochemistry}

Paraffin embedded tissues were retrieved. The surgical specimens were fixed in $10 \%$ formalin and embedded in paraffin. Four micrometer sections were stained with hematoxylin and eosin for conventional histopathologic examination. Fourmicrometer sections were processed for immunohistochemistry with the labeled streptavidin-biotin peroxidase detection system using the Ventana automated immunostainer (Ventana Medical Systems, Tucson, AZ) in accordance with the manufacturer's protocol.

The following primary antibodies were used: CAM5.2 (prediluted, Becton Dickinson, San Jose, CA, USA), AE1/AE3 (prediluted, Nichirei, Tokyo, Japan), SP52 (CK7, prediluted, Ventana Medical Systems), TS-1 (CK8, diluted 1:100, Leica Biosystems), DC10 (CK18, diluted 1:100, Leica Biosystems).

Cases in which $>10 \%$ of the tumor cells showed reactivity were considered to be positive for CAM 5.2 or AE1/AE3. The results were also estimated using a four-grade scale (reactivity: -, no/uncertain, $1+: \leq 10 \%, 2+: 10-50 \%,+3: \geq 50 \%$ ), as described previously. ${ }^{7}$

The results obtained using antibodies SP52 (CK7), TS-1 (CK8) and DC10 (CK18) antibodies were estimated using four grade scale. 


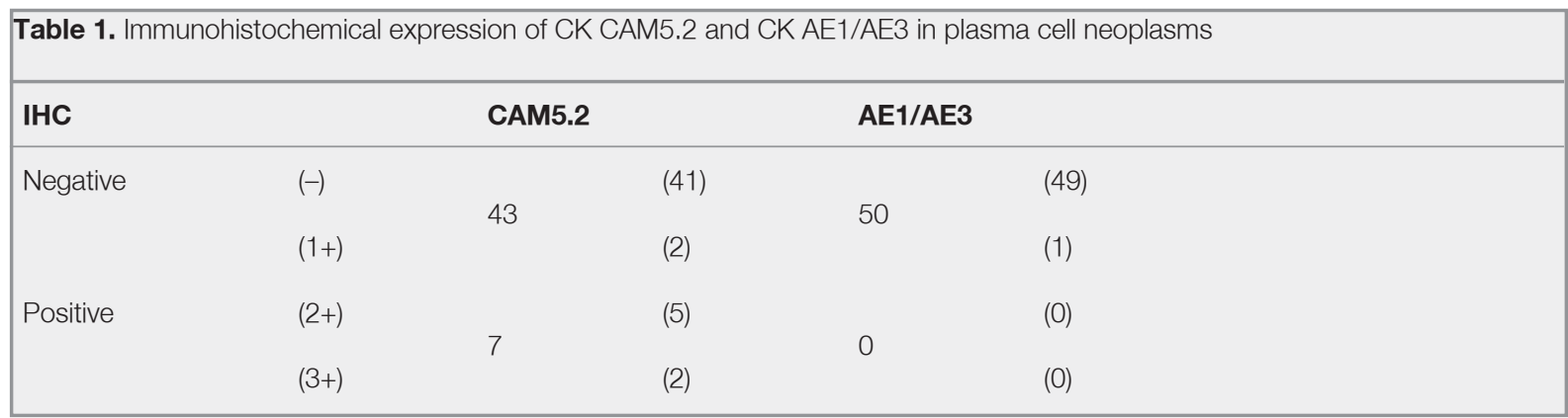

\section{Survival Analyses}

Overall survival (OS) was calculated from the date of the diagnosis to the date of death from any cause or the date of the last follow-up. OS was estimated by the Kaplan-Meier method and the significance of differences was assessed by a log-rank test.

\section{RESULTS}

Immunohistochemical staining was performed using CK CAM5.2 and CK AE1/AE3 for 50 consecutive cases involving plasma cell neoplasms.Seven of the fifty cases were positive for CK CAM5.2 and all 50 cases were negative for CK AE1/AE3 (cut-off level 10\%, Table 1). One case focally expressed CK AE1/AE3 $(<10 \%)$ and two cases focally expressed CK CAM5.2 $(<10 \%)$. These cases were considered to be "negative".

Representative results of hematoxylin-eosin staining and immunohistochemistry are shown in Figure 1. The tumor cells of case 6 (multiple myeloma) showed round and eccentric nuclei with an eosinophilic cytoplasm (Figure $1 \mathrm{~A}, \mathrm{~B}$ ). The tumor cells were diffusely positive for CD138 and kappa and negative for lambda (data not shown). The tumor cells diffusely expressed CK CAM 5.2 (positive, Figure 1, C) and focally expressed CK AE1/AE3 (negative, $<10 \%$, Figure 1, D).

The seven cases that were positive for CK CAM5.2 were selected for further immunohistochemistry using antibodies for CK18, CK8, and CK7. The immunohistochemistry results are summarized in Table 2. Six of the seven cases showed reactivity to CK18 (2+ or $3+$, positive) and one of the seven cases showed reactivity to CK8 ( $2+$, positive). All 7 cases were negative for CK7; however, two cases

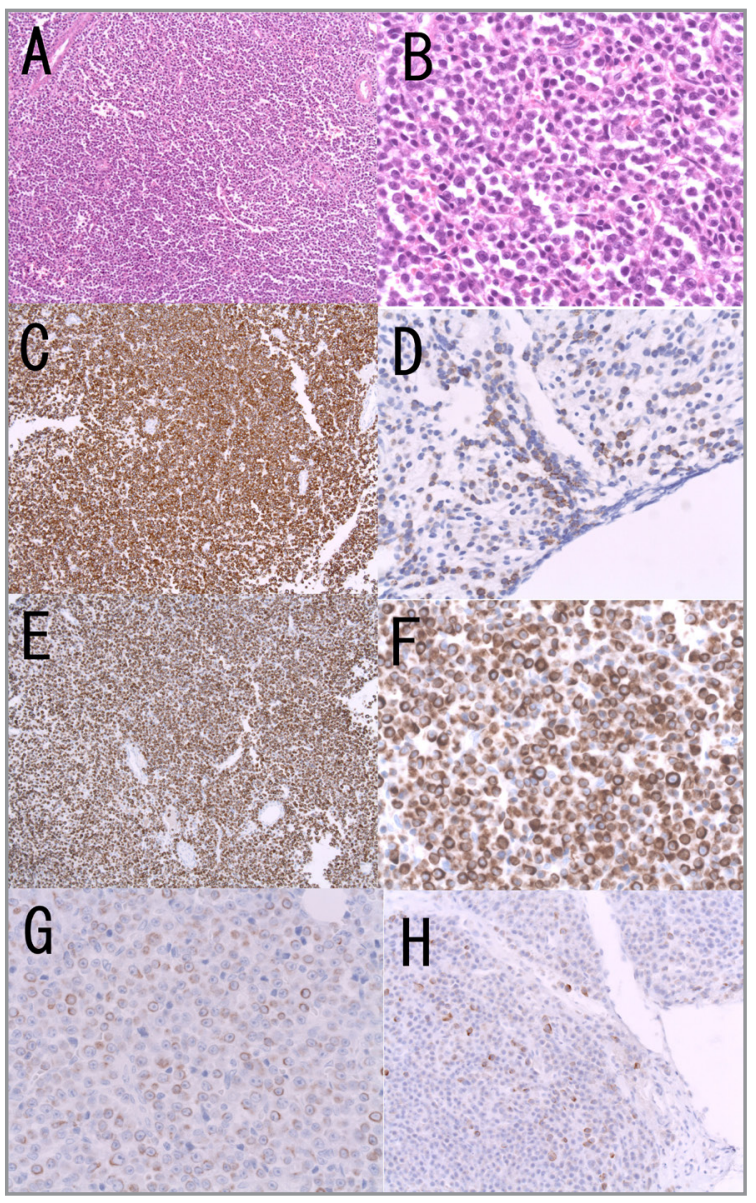

Figure 1. Photomicrographs of the plasma cell myeloma (case 6 and case1).

Diffuse bone marrow involvement of plasma cell myeloma was observed (A; HE, case 6, original magnification x6). Round and eccentric nuclei were seen (B; HE, case 6, original magnification x24). Tumor cells were diffusely positive for CK CAM5.2 (C; case 6, positive, original magnification $\times 6$ ). The tumor cells were focally positive for CK AE1/AE3 (D; case $6,<10 \%$, negative, original magnification, $\times 24)$. The tumor cells were diffusely positive for CK18 ( $E$ and F; case 6, 3+, original magnification, $x 6$ and $x 24)$. Tumor cells were moderately positive for CK8 (G; $2+$, original magnification, $\times 24)$. Tumor cells of case 1 were focally positive for keratin CK7 $(1+$, negative, $\mathrm{H}$, original magnification, $\mathrm{x} 12)$. 
Table 2. Immunohistochemical expression of CK7, 8, 18 in CAM5.2-positive plasma cell neoplasms.

\begin{tabular}{llllll}
\hline Case Number & CAM5.2 & AE1/AE3 & CK7 & CK8 & CK18 \\
\hline 1 & $2+$ & $(-)$ & $1+$ & $(-)$ & $2+$ \\
2 & $2+$ & $(-)$ & $(-)$ & $(-)$ & $2+$ \\
3 & $2+$ & $(-)$ & $(-)$ & $(-)$ & $1+$ \\
4 & $3+$ & $(-)$ & $(-)$ & $(-)$ & $2+$ \\
5 & $2+$ & $(-)$ & $(-)$ & $1+$ & $2+$ \\
6 & $3+$ & $1+$ & $(-)$ & $2+$ & $3+$ \\
7 & $2+$ & $(-)$ & $1+$ & $1+$ & $2+$
\end{tabular}

Reactivity: (-) No/uncertain, (1+) =<10\%, 2+ 10-50\%, 3+ =>50\%

focally expressed CK7 (1+). Representative results are also shown in Figure 1. Case 6 was positive for CK18 (3+, positive, Figure 1, E, F) and CK8 $(2+$, positive, Figure 1, G). Two of the seven cases (Case 1 and 7) showed weak reactivity to CK7 (1+, negative, case 1, Figure 1, H).

The overall survival curves of the patients in the CK CAM5.2-positive $(n=7)$ and CK CAM5.2negative $(n=43)$ groups are shown in Figure 2. No significant difference was observed in the overall survival of the CK CAM5.2-positive and CK5.2negative groups $(\mathrm{p}=0.639)$.

\section{DISCUSSION}

Our study showed that 7 of 50 plasma cell neoplasms were positive (>10\%) for CK CAM5.2, which was in line with previous reports. ${ }^{4,6,7} \mathrm{Six}$ of seven CAM5.2-positive plasma cell neoplasms were also positive for CK18 (>10\%) and one focally expressed CK18 $(\leq 10 \%)$. On the other hand, one case was CK8-positive and CK8 was focally expressed in 1 of the 7 CAM5.2-positive plasma cell neoplasms. One case was positive for both CK8 and CK18 and the other two cases expressed both CK8 and CK18. Thus, 3 cases expressed both CK8 and CK18. Our results showed that both CK8 and CK18 are simultaneously expressed in a subset of plasma cell neoplasms. It is known that CK8 (type II CK) and CK18 (type I CK) are expression partners and that they form heteropolymeric filaments in cells. ${ }^{2,3}$
CAM 5.2 is known to react primarily with CK8 and to a lesser extent with CK7. ${ }^{5}$ Heteropolymeric filaments are formed by the pairing of type I CK and type II CK in a 1:1 ratio., ${ }^{2,3}$ Kulesh et al. showed posttranslational regulation of CK8 and CK 18. ${ }^{9}$ The co-expression of both CK8 and CK 18 resulted in stabilization of both CK8 and CK18 and the single expression of CK8 or CK18 led to the degradation of the protein in cultured cells. ${ }^{9}$ Taken together, CAM 5.2 appeared to mainly react with CK8 in the 7 cases expressing CK18. It would be interesting to examine the CK8 expression using other antibodies; however, this would have been difficult because the biopsy materials were very limited.

Adams et al. reported the cytokeratin expression in hematological neoplasms using a tissue microarray. ${ }^{10}$ Immunohistochemistry was performed using monoclonal mouse anti-human CK cocktail CK22 antibodies and 866 of the arrayed cases were evaluable. Thirteen $(1.5 \%)$ of the cases were positive for CK22. The thirteen CK22 positive cases included Hodgkin and Reed-Sternberg cells of Hodgkin lymphoma $(0.4 \%, 1 / 230$ cases $)$, plasma cell myeloma ( $1 / 1$ case), diffuse large B-cell lymphoma $(0.6 \%, 2 / 326$ cases $)$, mantle cell lymphoma (26\%, $5 / 18$ cases), small cell lymphomas/chronic lymphocytic leukemias (4\%, 3/70 cases) and peripheral T-cell lymphoma, not otherwise specified (4\%, $1 / 27$ cases). They reported that the positive staining of $>10 \%$ of cells was only observed in the cases of Hodgkin lymphoma and plasma cell myeloma. 


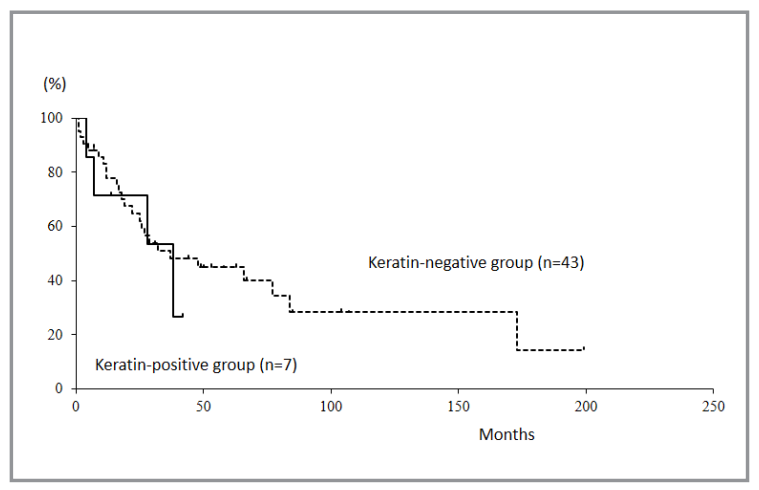

Figure 2. Overall survival curves of patients in the CK CAM5.2positive group and CK CAM5.2-negative group.

In the present study, the expression of cytokeratin was detected in $>10 \%$ of the tumor cells in $14 \%$ of plasma cell neoplasms. The rate and levels of cytokeratin expression in plasma cell neoplasms seemed to be high in comparison to other hematological neoplasms.

These results raised the question as to whether cytokeratin might have a role in the biological behavior of plasma cell myeloma. Gu et al. previously showed that cytokeratin was aberrantly expressed in $20 \%$ of Ewing sarcoma cases using cytokeratin CAM 5.2 and AE1/AE3. ${ }^{11}$ Recently, Sanker et al. suggested the role of CK 17 in coordinating oncogenic transformation and cellular adhesion in Ewing sarcoma. ${ }^{12}$ Taken together, aberrantly expressed CK may have a role in plasma cell neoplasms. An overall survival analysis was performed to investigate whether the expression of $\mathrm{CK}$ affected overall survival in patients with plasma cell myeoloma. No significant difference was found in the overall survival of the CK CAM5.2-positive and CK5.2negative groups $(p=0.639)$. However, it is still possible that CKs have a function in plasma cell neoplasms. Our results suggest that CKs form heteropolymeric filaments in a subset of plasma cell neoplasms, as described above. They could work as an intracellular scaffold for other molecules in plasma cell neoplasms.

\section{Acknowledgement}

The authors are grateful to Manabu Azuma and Miho Koseki for their technical assistance in the immunohistochemical analyses.

\section{REFERENCES}

1. McKenna RW, Kyle RA, Kuehi WM, et al. Plasma cell neoplasms. In: WHO classification of tumours of haematopoietic and lymphoid tissues. 4th ed. Lyon, 2008: 200-208.

2. Moll R, Divo M, Langbein $L$. The human keratins: biology and pathology. Histochem Cell Biol 129: 705-733, 2008.

3. Weng YR, Cui Y, Fang JY. Biological functions of cytokeratin 18 in Cancer. Mol Cancer Res 10: 485-493, 2012.

4. Sewell HF, Thompson WD, King DJ. IgD myeloma/immunoblastic lymphoma cells expressing cytokeratin. $\mathrm{Br} \mathrm{J}$ Cancer 53: 695-696, 1986.

5. Chang KL, Chao WR, Han CP. Anticytokeratin (CAM5.2) reagent identifies cytokeratins 7 and 8 , not cytokeratin 18. Chest 145: 1441-1442, 2014.

6. Wotherspoon AC, Norton AJ, Isaacson PG. Immunoreactive cytokeratins in plasmacytoma. Histopathol 14: 141-150, 1989.

7. Petruch UR, Horniy HP, Kaiserling E. Frequent expression of haemopoietic and non-haemopoietic antigens by neoplastic plasma cells: an immunohistochemical study using formalinfixed, paraffin-embedded tissue. Histpathol 20: 35-40, 1992.

8. Durie BGM, Salmon SE. A clinical staging system for multiple myeloma. Correlation of measured myeloma cell mass with presenting clinical features, response to treatment, and survival. Cancer 36: 842-854, 1975.

9. Kulesh DA, Cecena G, Darmon YM, et al. Posttranslational regulation of keratins: Degradation of mouse and human keratins 18 and 8. Mol Cell Biol 9: 1553-1565, 1989.

10. Adams H, Schmid P, Dirnhofer S, et al. Cytokeratin expression in hematological neoplasms: A tissue microarray study on 866 lymphoma and leukemia cases. Pathol Res Prac 204: 569-573, 2008.

11. Gu M, Antonescu CR, Guiter G, et al. Cytokeratin immunoreactivity in Ewing's sarcoma. Am J Surg Pathol 24: 410-416, 2008.

12. Sankar S, Tanner JM, Bell R, et al. A novel role for keratin 17 coordinating oncogenic transformation and cellular adhesion in Ewing Sarcoma. Mol Cell Biol 33: 4448-4460, 2013.

\section{Correspondence:}

Hiroaki SUZUKI

National Hospital Organization Hokkaido Cancer Center,

Division of Diagnostic Pathology

Kikusui 4-2, Shiroishi-ku,

Sapporo, 003-0804

JAPAN

Tel / Fax: +81-011-811-9111

e-mail: hsuzuki@sap-cc.go.jp 